\title{
High Performance Liquid Chromatography - Ultraviolet Method for the Determination of Fludioxonil Fungicide Residues: Application on Rice Grains Cultivated in Pakistan
}

\section{Aneeqa Khalid}

NED University of Engineering \&amp; Technology

Saeeda Nadir Ali ( $\nabla$ saeeda@neduet.edu.pk)

NED University of Engineering \&amp; Technology https://orcid.org/0000-0002-1783-5624

Amtul Qayoom

NED University of Engineering \&amp; Technology

Sajid lqbal

Jinnah Govt. College for Boys, Nazimabad

\section{Sadia Ansari}

NED University of Engineering \&amp; Technology

\section{Zahoor UI Hussain Awan}

NED University of Engineering \&amp; Technology

\section{Farah Kishwar}

Federal Urdu University of Arts Sciences and Technology

\section{Philippe Daniel}

Université du Maine: Le Mans Universite

\section{Research Article}

Keywords: Fludioxonil, Rice grains, Extraction, HPLC, Validation, MRL

Posted Date: April 5th, 2021

DOI: https://doi.org/10.21203/rs.3.rs-326017/v1

License: (c) (i) This work is licensed under a Creative Commons Attribution 4.0 International License. Read Full License

Version of Record: A version of this preprint was published at Arabian Journal of Chemistry on January 1st, 2022. See the published version at https://doi.org/10.1016/j.arabjc.2022.103692. 


\section{Abstract}

An analytical method was developed and validated for the determination of fludioxonil in rice samples. Rice samples for the study were collected from different regions of Pakistan. The method was based on safe and cost-effective extraction of fludioxonil from rice grains using acetone and methanol (1:1), efficient clean-up through homogenous mixture of acidic aluminum $(12 \mathrm{~g})$ and activated charcoal $(1 \mathrm{~g})$ followed by liquid chromatographic determination with UV detection. Quantification was performed on Prospher Star $\mathrm{C}_{18}(5 \mu \mathrm{m}, 25 \times 0.46 \mathrm{~cm})$ column maintaining the temperature $40^{\circ} \mathrm{C}$ and detector wavelength $212 \mathrm{~nm}$ using mobile phase 50:50 v/v methanol-water ( $\mathrm{pH} 3.3$ ) employing flow rate 1.0 $\mathrm{mL} \cdot \mathrm{min}^{-1}$ and $20 \mu \mathrm{L}$ injection volume. The method showed linearity with correlation coefficient greater than 0.998 . The proposed method was precisely validated for rice sample of all regions, showing recoveries higher than 98\%. Rice samples collected from Badin, Multan, Hyderabad, Lahore, Jahania and Sarghoda was found to have fludioxonil residues $0.046,0.045,0,043,0.040,0.024$ and $0.016 \mathrm{mg} . \mathrm{kg}^{-1}$ respectively, all below the maximum residual limit (MRL) level i.e. $0.05 \mathrm{mg}^{\mathrm{kg}} \mathrm{f}^{-1}$ whereas samples collected from Khanewal and Gularchi showed fludioxonil residue above MRL i.e 0.065 and $0.058 \mathrm{mg} . \mathrm{kg}^{-1}$ respectively. However, fludioxonil residues was not detected in rice sample collected from city Makhdumpur.

\section{Introduction}

Rice is the important staple sustenance and leading food commodity of developing world, which ranks third on the basis of its consumption. However rice crop is subjected to a number of diseases affecting its growth as well as quality and reducing the crop yield worldwide. Pakistan's chief summer crop is rice, which is cultivated over almost $11 \%$ area of total agricultural land distinguishing Pakistan as a top producer of rice commodity. Pakistani rice is famous for its taste and aroma and it is a major source of foreign export earnings. Punjab and Sindh are major rice producing provinces in Pakistan, and accounts for about $88 \%$ of total rice production (U.S. Department of Agriculture 2017).

Rice commodity is majorly affected by fungi e.g. fusarium species spoiled by penicillium and Aspergillus (Park et al. 2005). Fludioxonil, chemically 4-(2, 2-difluoro-1,3-benzodioxol-4-yl)-1H-pyrrole-3-carbonitril (Fig. 1) is non-systematic, colorless and odorless phenylpyrrole fungicide. It is strongly effective against fungal pathogens like stem-base browning, snow mold and seeding blight and can be used to inhibit black spot, gray mold and storage mold (Agostini et al. 2006; Li et al. 2014; Ren et al. 2016; Errampalli et al. 2006). It is applied on various fruits, vegetables and cereal crop (Zhao et al. 2010; Munitz, Resnik, and Montti 2013; Martinez et al. 2005; Edmunds and Holmes 2009; Gaurilcikiene et al. 2008). Literature survey reveals that unsafe interaction of fludioxonil can have negative health consequences on applicators and farmers. It's excessive exposure can cause diseases like cancer (Go et al. 2017), it is also toxic for aquatic life (Verdisson et al. 2001). CODEX ALIMENTARIUS standard has defined $0.05 \mathrm{mg} \mathrm{kg}^{-1}$ maximum residual limit (MRL) of fludioxonil for cereal grains (Codex Pesticides Residues in Food Online Database (2018). 
The determination of pesticide residues in food commodities is of major importance in relation to public health. Regular monitoring of pesticide residue is one of the necessary steps to achieve adequate level of consumer protection. Asia is on top in the world with highest average pesticide usage i.e. $6.5-60 \mathrm{~kg}^{-h^{-1}}$ (Carvalho 2017). Pakistan is the second largest pesticide consumer country in south Asia (Waheed et al. 2017). Various analytical methods have been reported for the quantitative determination of fludioxonil in variety of fruits, vegetables and food commodities. Residue of fludioxonil was quantitatively analyzed in blueberries (Munitz, Resnik, and Montti 2013) and in grape and lettuce (Marín et al. 2003) by GC-NPD. Otero et.al developed a gas chromatographic method for its determination in white wine (Otero et al. 2002). F.J. Camino-Sanchez (Camino-Sánchez et al. 2011) and D.Stajnbaher (Štajnbaher and ZupančičKralj 2003) determined different pesticides in vegetables and fruits by solid phase extraction followed by gas chromatography. Fludioxonil has been determined in fruits (Lee JY et al. 2012) and in the fermentative process of must (Vaquero-Fernández et al. 2008) by HPLC-DAD. Mercader et.al applied ELISA technique for fludioxonil determination in fruit juices (Mercader et al. 2014). However, in spite of importance of rice as one of the most common staple foods, very few studies have been conducted on determination of fludioxonil residues in rice e.g. fludioxonil residues were quantitatively analyzed in brown rice and rice straw by gas chromatographic method (Ko, Ah-Young et al. 2015). To the best of our knowledge, no liquid chromatographic methods-ultraviolet have been reported for fludioxonil residues in rice samples.

Present study reports development and validation of simple and cost effective liquid-chromatographic method with UV-detection for the determination of fludioxonil residues in rice grains. After appropriate pretreatment method for its extraction and purification, liquid chromatography with UV-detection was used as analytical technique followed by validation employing FDA guidelines (FDA 2015). Rice samples were collected from nine different regions of two major rice-producing provinces of Pakistan namely Punjab (Khanewal, Multan, Lahore, Jahania, Sarghoda and Makhdumpur) and Sindh (Gularchi, Badin Hyderabad).

\section{Experimental}

\subsection{Chemicals and reagents}

Fludioxonil (97\% pure) was supplied by Department of Plant Protection. Analytical grade solvents methanol (99\%), dichloromethane (98\%), acetone (98\%), anhydrous sodium sulfate and activated charcoal were purchased from Merck (Darmstadt, Germany). Chemically pure acidic aluminum oxide pH $4.5 \pm 0.5$, Brockmann activity grade I was purchased from Fluka (Switzerland). Filter membranes with pore size $0.45 \mu \mathrm{m}$ were purchased from Merck (Darmstadt, Germany).

\subsection{Instrumentation}

Liquid chromatographic system (Shimadzu Corporation, Japan) equipped with dual LC-20 AT solvent delivery modules connected with DGU-20A3/20A5 on-line degasser, fitted with rheodyne manual injector connected with SPD-20A/20AV UV/VIS detector and Shimadzu CBM-20A communication bus module. 
Data acquisition was performed on LC solution GPC Chromatographic software (version 1.25). $\lambda_{\max }$ was measured on Shimadzu-1800 double beam UV/vis spectrophotometer. Rotary evaporator (Heidolph $\mathrm{G}_{3}$ Germany) was used to concentrate the sample.

\subsection{Chromatographic conditions}

Separation was achieved on Purospher Star, $\mathrm{C}_{18}(5 \mu \mathrm{m}, 25 \times 0.46 \mathrm{~cm})$ column (Merck, Germany) maintaining the column temperature at $40^{\circ} \mathrm{C}$ with optimized parameters including mobile phase methanol: water 50:50 (v/v) with pH adjusted at 3.3 using o-phosphoric acid (85\%), observing detector response at $212 \mathrm{~nm}$. Fludioxonil was eluted isocratically maintaining flow rate $1.0 \mathrm{~mL} \cdot \mathrm{min}^{-1}$. Prior to introducing into the system, all the solutions were filtered through $0.45 \mu \mathrm{m}$ millipore filter followed by degassing on ultrasonic bath (Elma LC-30H model Singen, Germany).

\subsection{Calibration curve}

Accurately weighted $0.01 \mathrm{~g}$ fludioxonil standard was dissolved in $25 \mathrm{~mL}$ methanol to obtain $400 \mathrm{mg} . \mathrm{L}^{-1}$ stock standard solutions. It was prepared once and stored at $4^{\circ} \mathrm{C}$ protected from light. Six calibration standards of fludioxonil within the linearity range $0.25-16 \mu \mathrm{g} \cdot \mathrm{mL}^{-1}$ were prepared in $25 \mathrm{~mL}$ volumetric flask. Calibration standard were prepared fresh daily and filtered through $0.45 \mu \mathrm{m}$ filter before injecting in to the system.

\subsection{Method validation}

Validation of method was performed according to Food and Drug Administration (FDA) guidelines in term of accuracy, linearity, precision, specificity, system suitability, limit of detection (LOD) and limit of quantification (LOQ). Efficiency of column performance was evaluated in term of tailing factor, number of theoretical plates and capacity factor. Six different concentration levels were used for calibration study. Linearity and regression characteristics were evaluated by using intercept, slope, correlation coefficient, standard error and standard error estimate. Percent recovery was calculated to determine accuracy of the method. LOD and LOQ were also calculated. For robustness study, minor deliberate changes were introduced in order to check the persistence of method. A robust assay for analysis of fludioxonil was performed and validated. The chromatographic parameters were deliberately varied including mobile phase composition methanol: water $50: 50 \pm 2 \mathrm{~mL}, \mathrm{pH} 2.6-3.6$, wavelength $212 \mathrm{~nm} \pm 2$, flow rate in range of $0.7-1.2 \mathrm{~mL} \cdot \mathrm{min}^{-1}$ and chromatographic response was monitored.

\subsection{Rice sample analysis}

\subsubsection{Sample collection}

Control rice samples (free from fludioxonil) were obtained from crop disease research institute, PARC, Karachi. Nine samples were collected from two provinces of Pakistan, Punjab (Khanewal, Multan, Lahore, Jahania, Sarghoda and Makhdumpur) and Sindh (Gularchi, Badin, Multan, Hyderabad) for the crop year 2017-18 (Kharif 2017-18). Figure 2. presents distribution of rice sampling regions and strategy to obtain representative rice sample for the study. Purposeful sampling was carried out to get the representative 
samples. Rice field was equally divided into nine parts by sketching imaginary lines. Approximating $50 \mathrm{~g}$ of rice samples were randomly collected from each part, homogenously mixed and considered as one composite sample. All the nine composite samples were collected following the same strategy.

\subsubsection{Fortification}

Accurately weighed $100 \mathrm{~g}$ of all nine rice samples were separately soaked in $50 \mathrm{~mL}$ acetone followed by addition of $100 \mu \mathrm{L}$ of $10 \mathrm{ppm}$ fludioxonil working standard solution and homogenized. The contents were allowed to penetrate in rice grains by keeping in the dark for 24 hours. After the grains have been well dried, all the samples were separately pulverized with a mechanical hand grinder to increase the surface area and to ensure better extraction of fludioxonil from rice grain sample.

\subsubsection{Extraction}

The extraction was accomplished following the procedure described by Uddin et.al (Uddin et al. 2011). Along with fortified samples, a blank was also concurrently processed for extractions. Into a centrifuging tube, accurately weighed $4 \mathrm{~g}$ of already fortified and pulverized rice sample was transferred followed by addition of $75 \mathrm{~mL}$ mixture of acetone and methanol (1:1) in two times. The contents were vigorously stirred and centrifuged at $2500 \mathrm{rpm}$ for three minutes, supernatant was collected into the conical flask passing through Whatman filter paper supported by filter funnel. Into a separating funnel already containing $200 \mathrm{~mL}$ of $2.5 \%$ sodium sulfate solution, the filtered rice extract was transferred followed by addition of $25 \mathrm{~mL}$ of dichloromethane by rinsing the respective conical flask. The contents were vigorously stirred and then allowed for layer separation. The lower layer containing fludioxonil extract was collected in a conical flask; the procedure was repeated with addition of $25 \mathrm{~mL}$ portion of dichloromethane twice in order to get maximum extraction of fludioxonil. Furthermore, the contents were passed through the glass column containing about $25 \mathrm{~g}$ of anhydrous sodium sulfate $\left(\mathrm{Na}_{2} \mathrm{SO}_{4}\right)$ supported by glass wool. Finally, a $10 \mathrm{~mL}$ portion of dichloromethane was further passed to sweep the contents from the column completely. Analysis was performed in triplicate for each sample.

\subsubsection{Clean-up}

The extract (moisture-free) was concentrated up to 1-2 $\mathrm{mL}$ by rotary evaporator. The concentrated extract was carefully shifted to a glass column containing homogenous mixture of acidic aluminum (12 g) and activated charcoal $(1 \mathrm{~g})$ between the layers of anhydrous $\mathrm{Na}_{2} \mathrm{SO}_{4}$, followed by addition of $120 \mathrm{~mL}$ dichloromethane through the column. Prior to column preparation, acidic aluminum, charcoal and sodium sulfate were activated at $110^{\circ} \mathrm{C}$ for 6 hours.

\subsubsection{Preparation of sample for analysis}

The eluted extract was then placed on rotary evaporator for complete evaporation of solvent. The dried flask contains the expected residues of fludioxonil which was then dissolved in $2 \mathrm{~mL}$ methanol for its quantitative determination. The samples in $2 \mathrm{~mL}$ methanol were mostly observed to be opaque. The clear and transparent samples obtained by filtration through $0.45 \mu \mathrm{m}$ millipore filter paper was injected to the 
system for chromatographic analysis. Steps for extraction and clean-up were repeated for all the other samples before preparation for chromatographic analysis.

\section{Results And Discussion}

\subsection{Method Optimization}

In order to establish the optimum reliable analytical condition and to obtain the maximum sensitivity for identification and quantification of fludioxonil, numerous parameters were varied to set the best chromatographic condition. Firstly, the maximum wavelength of fludioxonil was measured on Shimadzu1800 double beam UV-vis spectrophotometer. Figure 3 represent the spectra of fludioxonil showing maximum wavelength at $212 \mathrm{~nm}$. Further instrumental parameters including flow rate, composition and ratio of mobile phase and its $\mathrm{pH}$ were separately studied by injecting $10 \mu \mathrm{g} \cdot \mathrm{mL}^{-1}$ fludioxonil standard solution prepared in methanol into the chromatograph. Furthermore, in order to get the improved selectivity in reversed-phase high performance liquid chromatography (HPLC), different combination of organic solvents were tried such as acetonitrile:water and methanol:water. It was observed that increasing the percentage of organic modifier causes a reduction in retention i.e. acetonitrile showed less retention time of analyte as compare to methanol. However, because of being carcinogenic nature of acetonitrile, methanol was preferred. Methanol:water in the ratio 80:20, 70:30, 60:40 and 50:50 with pH in the range 2.0-4.0 were tried in order to avoid retention and selectivity changes. The flow rate of mobile phase was varied between $0.7 \mathrm{~mL} \cdot \mathrm{min}^{-1}$ and $1.2 \mathrm{~mL} \cdot \mathrm{min}^{-1}$. The best results in terms of short retention time, high resolution and good peak symmetry were obtained with mobile phase ratio 50:50 v/v methanol: water adjusting eluent pH 3.3 at detector wavelength $212 \mathrm{~nm}$ and flow rate $1.0 \mathrm{~mL} \cdot \mathrm{min}^{-1}$. The representative chromatogram of standard fludioxonil is shown in Fig. 4.

\subsection{Method validation}

In order to establish the appropriateness of method for its future application, developed method was validated according to Food and Drug Administration (FDA) guidelines. Validated parameters include system suitability, linearity, precision, accuracy, limit of detection, limit of quantification and robustness (FDA 2015).

\subsubsection{System suitability test}

System suitability is an important step of method validation which represents the efficiency of column. It was evaluated by injecting the standard fludioxonil solution into the system six times on each day of analysis. The data obtained for system suitability of the proposed method represented in Table 1 shows capacity factor $\left(k^{\prime}\right)$ 2.177, theoretical plates $(N)$ 5106, tailing factor $(T) 1.16$ and separation factor (a) 1.22. Number of theoretical plates above 2000 and tailing factor below 2 show good system suitability of the method. 
Table 1

System suitability parameters for the analysis of fludioxonil

\begin{tabular}{|llllll|}
\hline Parameters & $\begin{array}{l}\text { Retention time } \\
\text { (min.) }\end{array}$ & $\begin{array}{l}\text { Theoretical } \\
\text { plates }\end{array}$ & $\begin{array}{l}\text { Tailing } \\
\text { factor }\end{array}$ & $\begin{array}{l}\text { Capacity } \\
\text { factor }\end{array}$ & $\begin{array}{l}\text { Separation } \\
\text { factor }\end{array}$ \\
\hline Fludioxonil & 2.7 & 5106 & 1.616 & 2.177 & 1.22 \\
\hline
\end{tabular}

\subsubsection{Linearity}

Calibration curve was plotted by triplicate analysis of seven different calibration standards of fludioxonil in methanol:water 80:20 (v/v) diluent in the range 0.25 to $16 \mu \mathrm{g} \cdot \mathrm{mL}^{-1}$. Regression data showed correlation coefficient 0.998 , which lie in the acceptable range, established by FDA guidelines. Linearity and regression data including slope and intercept are represented in Table 2.

Table 2

Regression characteristics for the analysis of fludioxonil

\begin{tabular}{|llllll|}
\hline $\begin{array}{l}\text { Linearity } \\
\left(\mu \mathrm{g} \cdot \mathrm{mL}^{-1}\right)\end{array}$ & Slope & Intercept & $\begin{array}{l}\text { Correlation } \\
\text { coefficient }\end{array}$ & $\begin{array}{l}\text { LOD } \\
\left(\mu \mathrm{g} \cdot \mathrm{mL}^{-1}\right)\end{array}$ & $\begin{array}{l}\text { LOQ } \\
\left(\mu \mathrm{g} \cdot \mathrm{mL}^{-1}\right)\end{array}$ \\
\hline $0.25-16$ & 35549 & 1079.8 & 0.998 & 0.0042 & 0.0126 \\
\hline
\end{tabular}

\subsubsection{Precision}

Repeatability and precision of our method was confirmed by introducing the seven calibration standard of fludioxonil three times within the same day (intra-day precision) and on two consecutive days (interday precision) of method validation. The \% relative standard deviation (RSD) values within-day and in between two consecutive days was found to be in the range $0.63-1.71 \%$ and $0.09-1.33 \%$ respectively. Results expressed in Table 3 in terms of relative standard deviation (RSD) lie in the acceptance criteria. 
Table 3

Recoveries, repeatability and precision data of fludioxonil in $0.10 \mathrm{mg} . \mathrm{kg}-1$ fortified rice grain samples of different regions of Pakistan

\begin{tabular}{|lllll|}
\hline Location of rice grain sample & \multicolumn{3}{c|}{ Intra-day } & \multicolumn{3}{l|}{ Inter-day } \\
\cline { 2 - 5 } & \% RSD* & \% Recovery & \% RSD* & \% Recovery \\
\hline Khanewal & 1.05 & 100.45 & 0.09 & 103.30 \\
\hline Gularchi & 0.63 & 105.64 & 0.76 & 99.32 \\
\hline Badin & 1.07 & 99.10 & 1.14 & 101.16 \\
\hline Multan & 1.49 & 98.32 & 0.74 & 98.52 \\
\hline Hyderabad & 1.71 & 99.89 & 1.33 & 99.26 \\
\hline Lahore & 0.96 & 101.19 & 0.72 & 101.02 \\
\hline Jahania & 0.92 & 99.31 & 0.80 & 99.89 \\
\hline Sarghoda & 1.29 & 99.91 & 0.53 & 100.78 \\
\hline Makhdumpur & 1.26 & 98.26 & 0.32 & 99.96 \\
\hline * $n=3$ & & & & \\
\hline
\end{tabular}

\subsubsection{Accuracy}

Accuracy, one of the foremost parameter of method validation, was evaluated in the term of percentage recovery of fludioxonil from rice sample. Recoveries were determined by adding known amount of fludioxonil $\left(0.10 \mu \mathrm{g} . \mathrm{kg}^{-1}\right)$ in rice grain samples of Punjab and Sindh. The recoveries were observed between $98.26-105.64 \%$ and $98.52-103.30 \%$ for two consecutive days of analysis (Table 3 ).

\subsubsection{Limit of detection and quantification}

Detection and quantitation limits of fludioxonil were determined in relation to the chromatographic signal higher than three times and ten times to the baseline noise respectively. LOD and LOQ of fludioxonil were found to be 0.0042 and $0.0126 \mu \mathrm{g} \cdot \mathrm{mL}^{-1}$ demonstrating the suitability of proposed method with respect to MRL for fludioxonil in rice grains (Table 2).

\subsubsection{Robustness}

The robustness of the proposed method was assessed by evaluating the capability of method to withstand intended variation in the chromatographic parameters of developed analytical method. Parameters including mobile phase composition and $\mathrm{pH}$, wavelength and flow rate were intentionally changed and compatibility of method was assessed. Theoretical plates and tailing factor represented in Table 4 confirms suitability of method for routine analysis. 
Table 4

Robustness of the proposed method for the detection of fludioxonil

\begin{tabular}{|lllll|}
\hline Parameters & Variation & Tailing factor & Capacity factor & Theoretical plates \\
\hline Flow rate $\left(\mathrm{mL} \cdot \mathrm{min}^{-1}\right)$ & 0.9 & 1.184 & 2.683 & 4973 \\
\cline { 2 - 5 } & 1.0 & 1.227 & 2.075 & 5227 \\
\cline { 2 - 5 } & 1.1 & 1.163 & 2.483 & 5307 \\
\hline Wavelength $(\mathrm{nm})$ & 210 & 1.104 & 2.378 & 5107 \\
\hline Mobile phase & 212 & 1.027 & 2.075 & 5429 \\
\hline & 214 & 0.980 & 2.889 & 5094 \\
\hline & $58: 52$ & 1.173 & 2.219 & 5004 \\
\hline
\end{tabular}

\subsection{Recovery of fludioxonil}

The applicability of the proposed method was assessed by analyzing detection level of fludioxonil in rice grains collected from the rice producing fields of Punjab and Sindh for the crop year 2017-18 (Kharif crop 2017-18). Evaluation was performed by comparing the un-spiked rice samples using spiked one at 1.0 $\mu \mathrm{g} . \mathrm{g}^{-1}$ fortification level. The spiked samples were prepared by transferring known quantity of fludioxonil to $4 \mathrm{~g}$ finely ground rice sample separately followed by extraction and purification. The un-spiked rice samples were simultaneously processed along with spiked ones for recovery check. The extraction recovery values were obtained as average of triplicate measurement and compared with maximum residual limit (MRL) i.e. $0.05 \mathrm{mg} \cdot \mathrm{kg}^{-1}$. The fludioxonil residue was detected to be below MRL level i.e. $0.046,0.043,0.045$ and $0.040 \mathrm{mg} . \mathrm{kg}^{-1}$ in Badin, Hyderabad, Multan and Lahore. It was found to be very low in Sargodha and Jahania samples i.e 0.016 and $0.024 \mathrm{mg} \cdot \mathrm{kg}^{-1}$ respectively. The data represents that skilled or trained farmer had monitored the field and rice samples cultivated in the fields of Badin, Hyderabad, Multan and Lahore are safe for consumption. The fludioxonil concentration was high in Khanewal and Gularchi samples i.e 0.065 and $0.058 \mathrm{mg} \cdot \mathrm{kg}^{-1}$ respectively. It represents that untrained farmers had excessively sprayed the pesticide on rice field without considering its potential dangerous effects. Fludioxonil was not detected in rice sample collected from city Makhdumpur. It may be due to human error or it is possible that its quantity is below the detection limit. One possible reason may be that fludioxonil have not been sprayed in the field. The results are represented in Table 5 and comparison of chromatographic response of un-spiked and spiked samples has been depicted in Fig. 5 . 
Table 5

Detection of fludioxonil in rice grain samples collected from nine different regions of Pakistan

\begin{tabular}{|ll|}
\hline Location of rice grain sample & $\begin{array}{l}\text { Detection level } \\
\left(\mathbf{m g} \cdot \mathbf{k g}^{-1} \mathbf{)}\right.\end{array}$ \\
\hline Khanewal & 0.065 \\
\hline Gularchi & 0.058 \\
\hline Badin & 0.046 \\
\hline Multan & 0.045 \\
\hline Hyderabad & 0.043 \\
\hline Lahore & 0.040 \\
\hline Jahania & 0.024 \\
\hline Sarghoda & 0.016 \\
\hline Makhdumpur & ND* \\
\hline *Not detected & \\
\hline
\end{tabular}

\section{Conclusion}

An inexpensive, simple and efficient LC-UV method for quantitative determination of fludioxonil residues in rice commodity has been reported for the laboratories that don't have access to modern extraction techniques. Developed method has been successfully applied for analysis of rice samples that were collected from Khanewal, Gularchi, Badin, Multan, Hyderabad, Lahore, Jahania, Sarghoda and Makhdumpur region of Punjab and Sindh. Analysis involved extraction of fludioxonil from rice with reduced amount of solvent and less matrix effect. Chromatographic analysis presented the sensitivity and specificity for the fludioxonil determination in rice samples; the method was then validated according to the FDA guidelines 2015, proving suitability of method. Results demonstrated satisfactory recovery and reproducibility confirming excellent accuracy and precision of method. Results demonstrated detection of fludioxonil in rice samples collected from Badin, Multan, Hyderabad, Lahore, Jahania and Sarghoda were found to be below its MRL level whereas its concentration was high in Khanewal and Gularchi samples. However, it was not detected in rice sample collected from city Makhdumpur. It is concluded that the proposed method can be applied in the laboratories those are not equipped with recent extraction techniques and modern instruments.

\section{Declarations}

Ethics approval and consent to participate 
Not applicable because the manuscript does not contain any individual's/person data.

\section{Consent for publication}

Not applicable.

\section{Availability of data and materials}

All the data generated or analyzed during this study are included within the article.

\section{Competing interests}

The authors declare that they have no known competing financial interest or personal relationship that cud have appear to influence the work reported in this paper.

\section{Funding}

HEC-SRGP research grant for project (Project \# 21-250/SRGP/RnD/HEC/2014).

\section{Authors' contributions}

Saeeda Nadir Ali was the incharge of overall direction and planning. Saeeda Nadir Ali and Sajid Iqbal conceived and planned the experiments. Zahoor UI Hussain Awan and Farah Kishwar provided rice samples after their pre- treatment. Aneeqa Khalid and Sadia Ansari performed the experiments. Amtul Qayoom interpreted the experimental data. Aneeqa Khalid wrote the manuscript in consultation with Saeeda Nadir Ali and Amtul Qayoom. Philippe Daniel verified the analytical method and discussed the analytical results, provided feedback and approved the version to be published.

\section{Acknowledgements}

Authors acknowledge Higher Education Commission, Pakistan for SRGP research grant for project (Project \# 21-250/SRGP/RnD/HEC/2014).

\section{Authors' information (optional)}

Aneeqa Khalid: Research Scholar, Department of Chemistry, NED University of Engineering and Technology, Karachi.

Saeeda Nadir Ali: Associate Professor, Department of Chemistry, NED University of Engineering and Technology, Karachi.

Amtul Qayoom: Associate Professor, Department of Chemistry, NED University of Engineering and Technology, Karachi.

Sajid Iqbal: Department of Chemistry, Jinnah Govt.College for Boys, Nazimabad Karachi, Karachi. 
Sadia Ansari: Research Scholar, Department of Chemistry, NED University of Engineering and Technology, Karachi.

Zahoor Ul Hussain Awan: Professor and Chairman, Department of Food Engineering, NED University of Engineering and Technology, Karachi

Farah Kishwar: Assistant Professor, Department of Chemistry, Federal Urdu University of Arts, Science and Technology, Karachi.

Philippe Daniel: Institut des Molécules et des Matériaux du Mans, UMR CNRS 6283, Université du Maine, Le Mans, France.

\section{References}

1. Agostini, JP_, N A Peres, S J Mackenzie, J E Adaskaveg, and L W Timmer. 2006. "Effect of Fungicides and Storage Conditions on Postharvest Development of Citrus Black Spot and Survival of Guignardia Citricarpa in Fruit Tissues." Plant Disease 90 (11): 1419-24.

2. Camino-Sánchez, F J, A Zafra-Gómez, J Ruiz-García, R Bermúdez-Peinado, O Ballesteros, A Navalon, and José L Vílchez. 2011. "UNE-EN ISO/IEC 17025: 2005 Accredited Method for the Determination of 121 Pesticide Residues in Fruits and Vegetables by Gas Chromatography-Tandem Mass Spectrometry." Journal of Food Composition and Analysis 24 (3): 427-40.

3. Carvalho, Fernando P. 2017. "Pesticides, Environment, and Food Safety." Food and Energy Security 6 (2): 48-60. https://doi.org/10.1002/fes3.108.

4. "Codex Pesticides Residues in Food Online Database (2018) Http://Www.Fao.Org/Fao-WhoCodexalimentarius/Codex-Texts/Dbs/Pestres/Pesticides/En/. Accessed May 2020." n.d.

5. Edmunds, Brooke A, and Gerald J Holmes. 2009. "Evaluation of Alternative Decay Control Products for Control of Postharvest Rhizopus Soft Rot of Sweetpotatoes." Plant Health Progress.

6. Errampalli, Deena, Nichole R Brubacher, and Jennifer R DeEll. 2006. "Sensitivity of Penicillium Expansum to Diphenylamine and Thiabendazole and Postharvest Control of Blue Mold with Fludioxonil in 'McIntosh'Apples." Postharvest Biology and Technology 39 (1): 101-7.

7. FDA, U S. 2015. "Guidance for Industry: Analytical Procedures and Methods Validation for Drugs and Biologics." US Department of Health and Human Services, FDA, Center for Drug Evaluation and Research. FDA, Rockville, MD.

8. Gaurilcikiene, Irena, Skaidre Suproniene, and Antanas Ronis. 2008. "The Impact of the Biological Agent Biojodis on the Incidence of Pathogenic Fungi in Winter Wheat and Spring Barley." Zemdirbyste-Agriculture 95 (3): 406-14.

9. Go, Ryeo-Eun, Cho-Won Kim, So-Ye Jeon, Yong-Sub Byun, Eui-Bae Jeung, Ki-Hoan Nam, and KyungChul Choi. 2017. "Fludioxonil Induced the Cancer Growth and Metastasis via Altering EpithelialMesenchymal Transition via an Estrogen Receptor-dependent Pathway in Cellular and Xenografted Breast Cancer Models." Environmental Toxicology 32 (4): 1439-54. 
10. “Https://Www.Agrochart.Com/En/News/2833/Pakistan-Rice-Annual-Apr-2015.Html.” n.d. Pakistan. Rice Annual. Apr 2015 May 12, 2015.

11. Ko, Ah-Young, A. M. Abd El-Aty, Jin Jang, Jeong-Heui Choi, Md Musfiqur Rahman, Sung-Woo Kim, HoChul Shin, Jae-Han Shim. 2015. "Detecting Fludioxonil Residues in Brown Rice and Rice Straw Using Gas Chromatography-Nitrogen Phosphorus Detector." Journal of the Korean Society for Applied Biological Chemistry 58 (2): 213-17.

12. Lee JY, Hong SM, Kim TK, Min ZW, Kim YH, Song K, Kwon HY, Lee HD, Im GJ, Kim DH, Kim JE. 2012. "Modified QuEChERS Multi-Residue Analysis Method for 61 Pesticides in Fruits Using with HPLC and GC-ECD/NPD." The Korean Journal of Pesticide Science 16 (3): 242-56.

13. Li, Xingpeng, Dolores Fernández-Ortuño, Anja Grabke, and Guido Schnabel. 2014. "Resistance to Fludioxonil in Botrytis Cinerea Isolates from Blackberry and Strawberry." Phytopathology 104 (7): 724-32.

14. Marín, Antonio, José Oliva, Carlos Garcia, Simón Navarro, and Alberto Barba. 2003. “Dissipation Rates of Cyprodinil and Fludioxonil in Lettuce and Table Grape in the Field and under Cold Storage Conditions." Journal of Agricultural and Food Chemistry 51 (16): 4708-11.

15. Martinez, Carole, C André Lévesque, Richard R Bélanger, and Russell J Tweddell. 2005. "Evaluation of Fungicides for the Control of Carrot Cavity Spot." Pest Management Science 61 (8): 767-71.

16. Mercader, Josep V, Antonio Abad-Fuentes, Consuelo Agulló, Antonio Abad-Somovilla, and Francesc A Esteve-Turrillas. 2014. "Development of a Sensitive and Specific Enzyme-Linked Immunosorbent Assay for the Determination of Fludioxonil Residues in Fruit Juices." Analytical Methods 6 (22): 8924-29.

17. Munitz, Martín S, Silvia L Resnik, and María I T Montti. 2013. "Method Development and Validation for Cyprodinil and Fludioxonil in Blueberries by Solid-Phase Microextraction Gas Chromatography, and Their Degradation Kinetics." Food Additives \& Contaminants: Part A 30 (7): 1299-1307.

18. Otero, R Rial, C Yagüe Ruiz, B Cancho Grande, and J Simal Gándara. 2002. "Solid-Phase Microextraction-Gas Chromatographic-Mass Spectrometric Method for the Determination of the Fungicides Cyprodinil and Fludioxonil in White Wines." Journal of Chromatography A 942 (1-2): $41-$ 52.

19. Park, Je Won, Sang-Youn Choi, Han-Joon Hwang, and Young-Bae Kim. 2005. "Fungal Mycoflora and Mycotoxins in Korean Polished Rice Destined for Humans." International Journal of Food Microbiology 103 (3): 305-14.

20. Ren, Weichao, Wenyong Shao, Xu Han, Mingguo Zhou, and Changjun Chen. 2016. "Molecular and Biochemical Characterization of Laboratory and Field Mutants of Botrytis Cinerea Resistant to Fludioxonil." Plant Disease 100 (7): 1414-23.

21. Štajnbaher, Darinka, and Lucija Zupančič-Kralj. 2003. "Multiresidue Method for Determination of 90 Pesticides in Fresh Fruits and Vegetables Using Solid-Phase Extraction and Gas ChromatographyMass Spectrometry." Journal of Chromatography A 1015 (1-2): 185-98.

22. U.S. Department of Agriculture. 2017. "Pakistan: Grain and Feed Annual." 
23. Uddin, Riaz, Sajid Iqbal, Muhammad Farhanullah Khan, Zahida Parveen, Mubarik Ahmed, and Muhammad Abbas. 2011. "Determination of Pesticide Residues in Rice Grain by Solvent Extraction, Column Cleanup, and Gas Chromatography-Electron Capture Detection." Bulletin of Environmental Contamination and Toxicology 86 (1): 83-89.

24. Vaquero-Fernández, Luis, Ana Sáenz-Hernáez, Jesús Sanz-Asensio, Purificación Fernández-Zurbano, Miguel Sainz-Ramírez, Begoña Pons-Jubera, Miguel López-Alonso, Sara-Isabel Epifanio-Fernández, and María-Teresa Martínez-Soria. 2008. "Determination of Cyprodinil and Fludioxonil in the Fermentative Process of Must by High-performance Liquid Chromatography-Diode Array Detection." Journal of the Science of Food and Agriculture 88 (11): 1943-48.

25. Verdisson, Sandrine, Michel Couderchet, and Guy Vernet. 2001. "Effects of Procymidone, Fludioxonil and Pyrimethanil on Two Non-Target Aquatic Plants." Chemosphere 44 (3): 467-74.

26. Waheed, Sidra, Crispin Halsall, Andrew J. Sweetman, Kevin C. Jones, and Riffat Naseem Malik. 2017. "Pesticides Contaminated Dust Exposure, Risk Diagnosis and Exposure Markers in Occupational and Residential Settings of Lahore, Pakistan." Environmental Toxicology and Pharmacology 56 (December): 375-82. https://doi.org/10.1016/j.etap.2017.11.003.

27. Zhao, H, Y K Kim, L Huang, and C L Xiao. 2010. "Resistance to Thiabendazole and Baseline Sensitivity to Fludioxonil and Pyrimethanil in Botrytis Cinerea Populations from Apple and Pear in Washington State." Postharvest Biology and Technology 56 (1): 12-18.

\section{Figures}

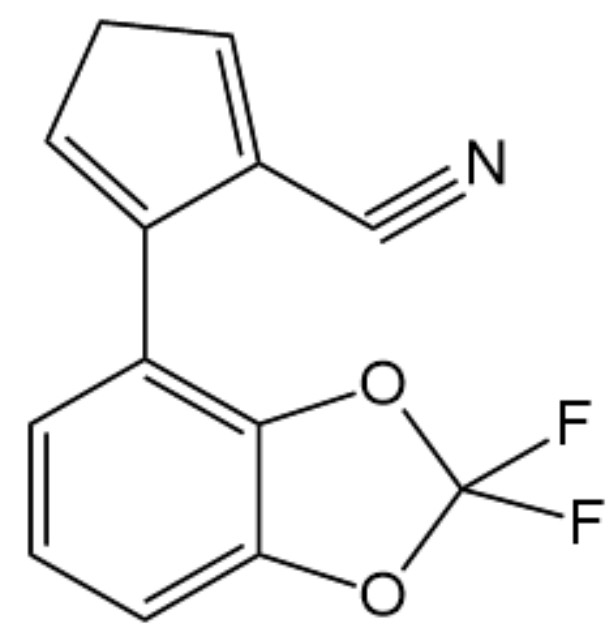

\section{Figure 1}

Representative structural formula of fludioxonil 


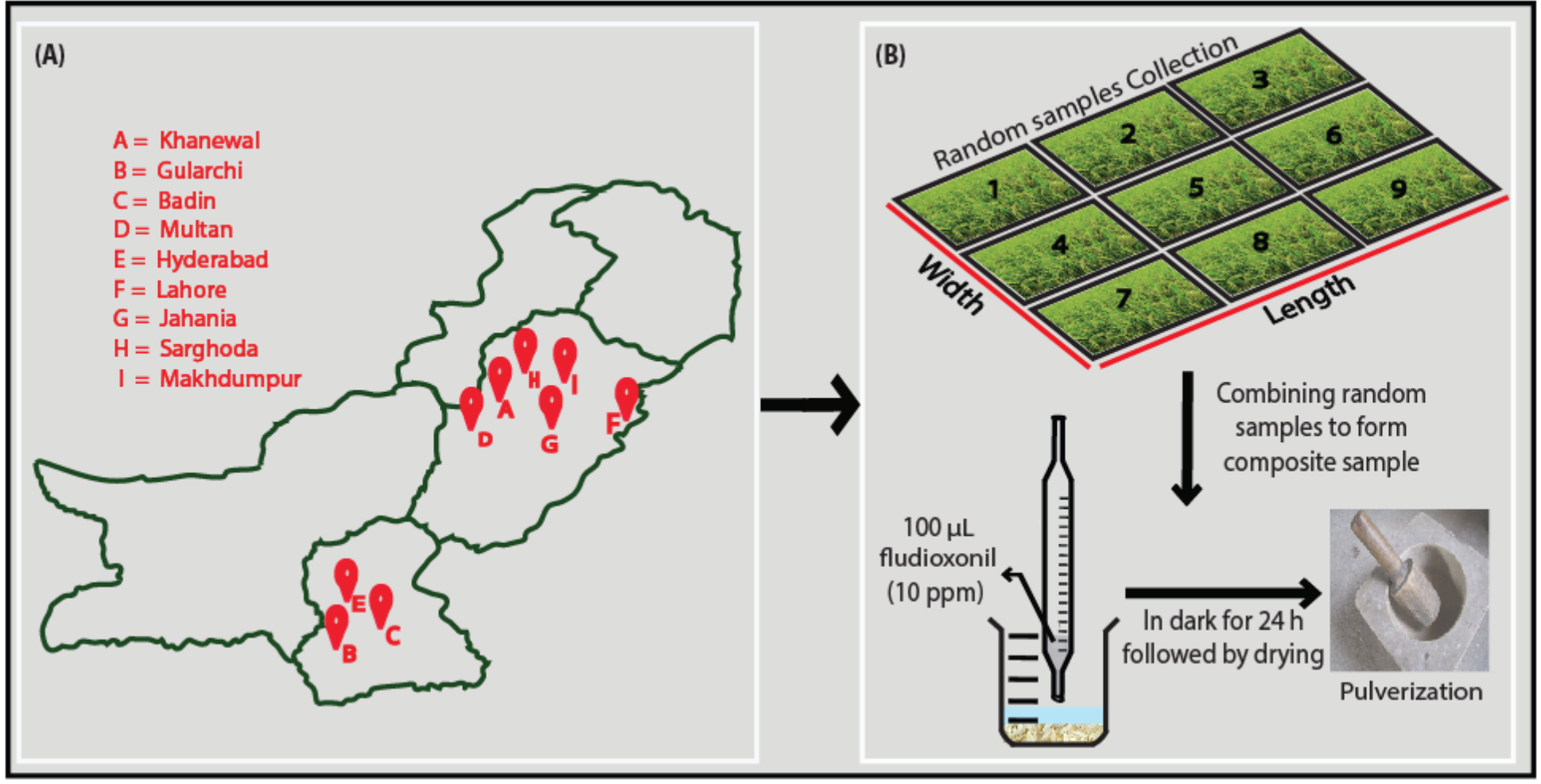

Figure 2

Rice sampling regions (A) and strategy to obtain representative rice sample (B) 


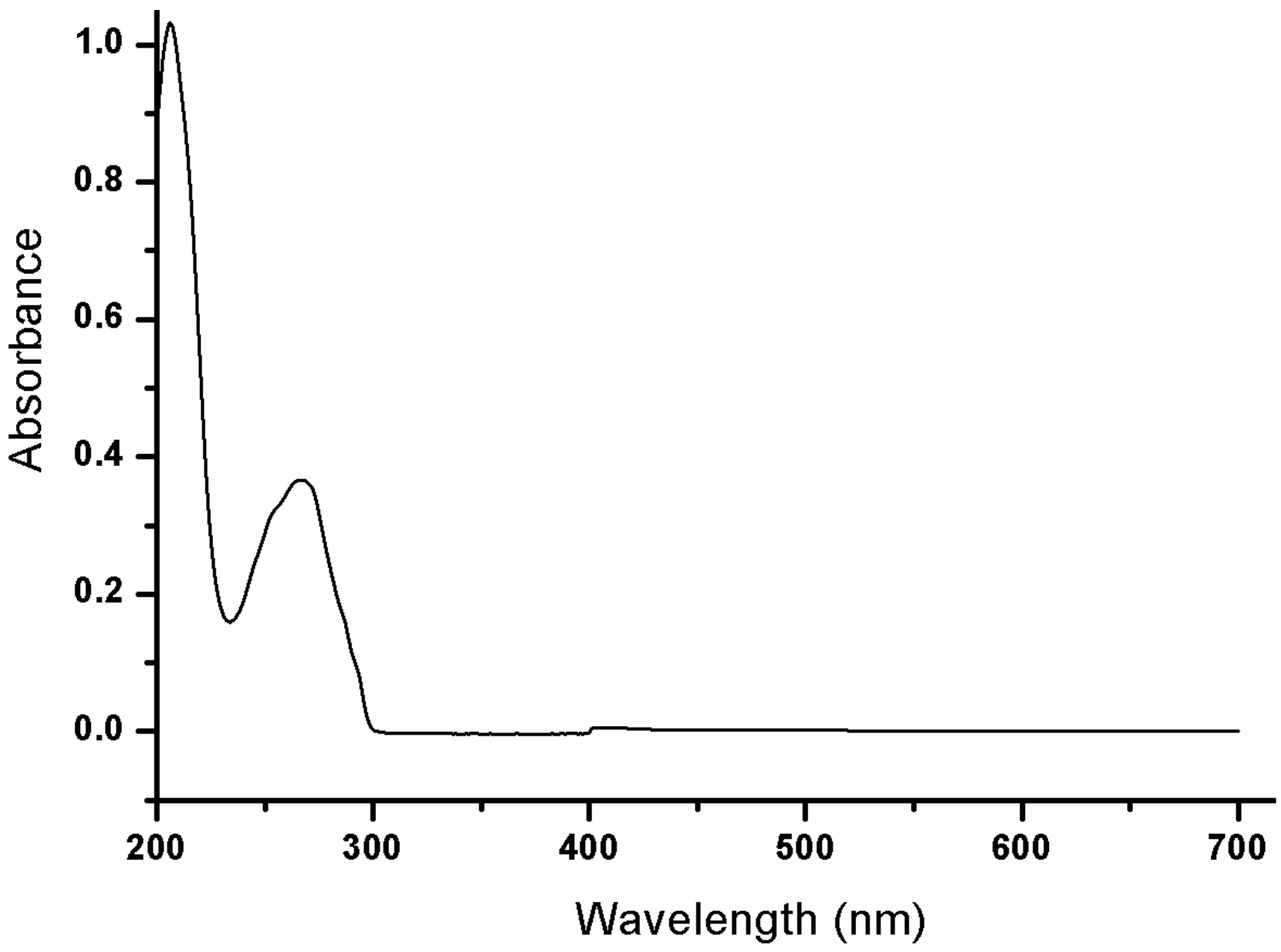

Figure 3

UV-visible spectra of fludioxonil standard in methanol 


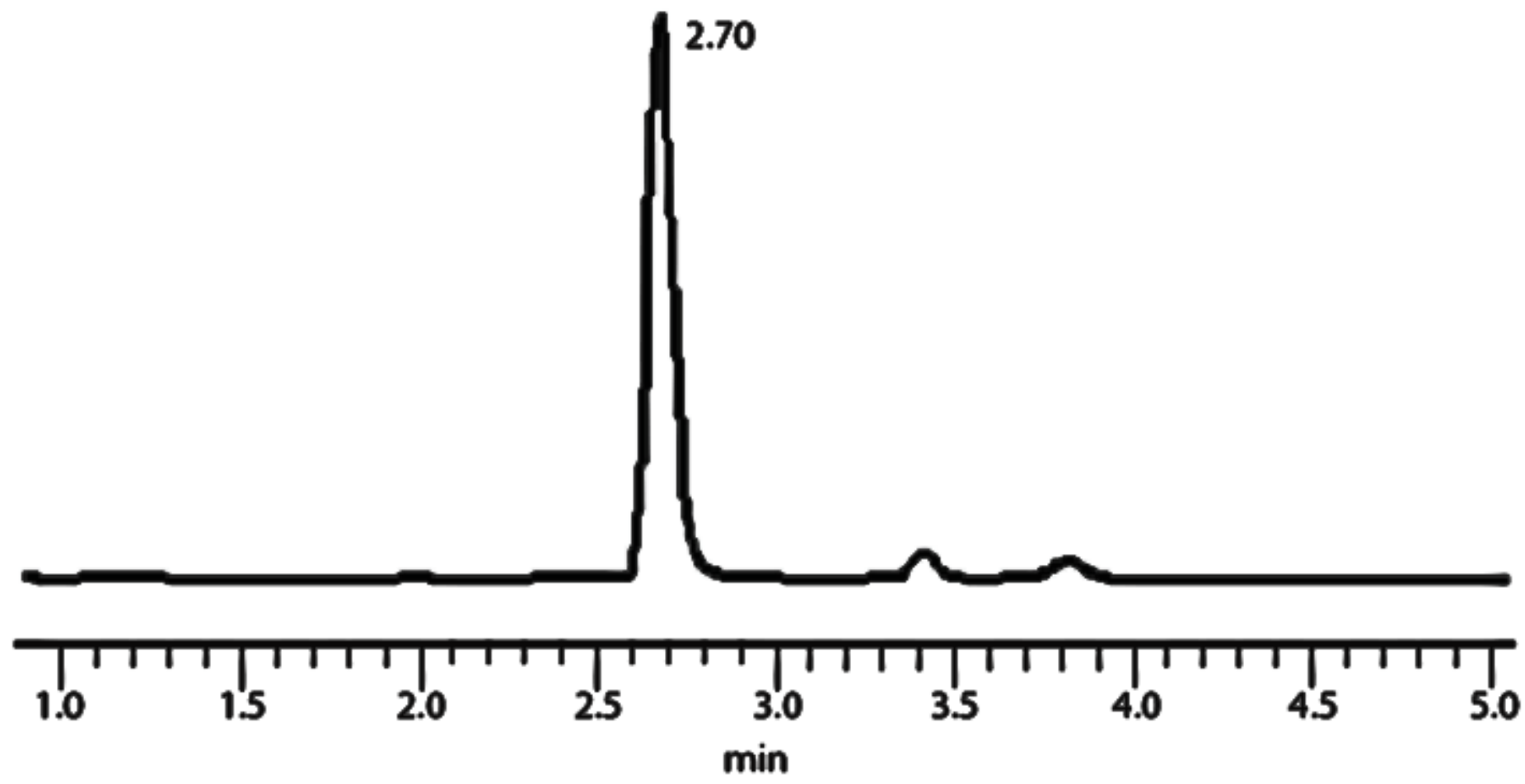

Figure 4

Representative chromatogram of fludioxonil $400 \mathrm{mg} . \mathrm{kg}-1$ in reference standard 


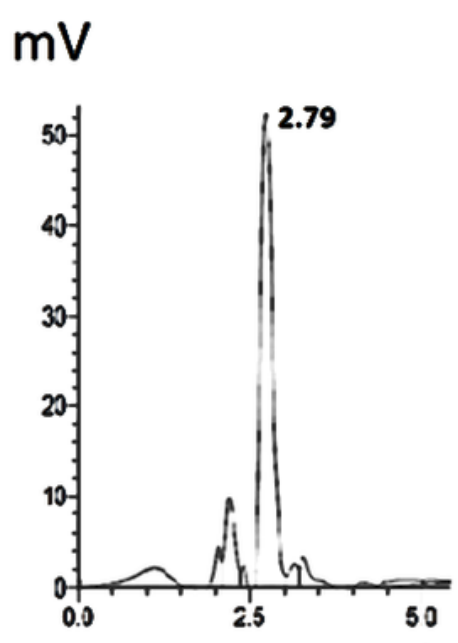

(a)

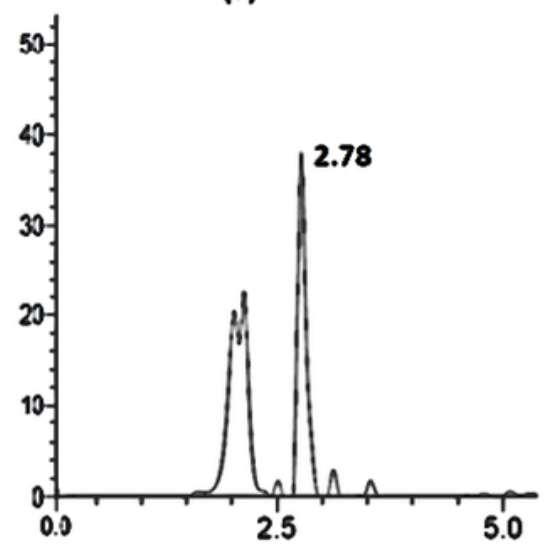

(d)

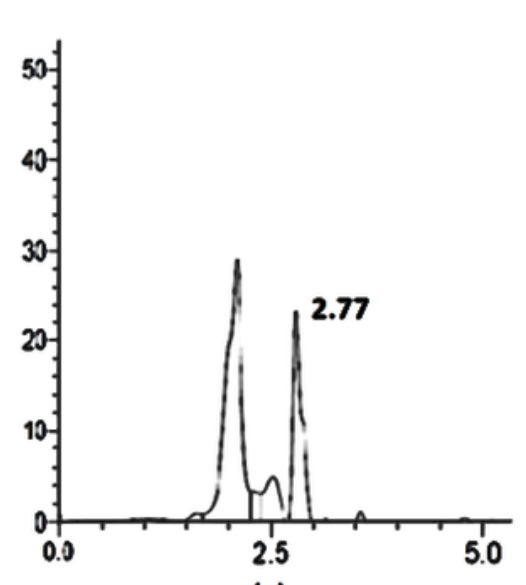

(g)

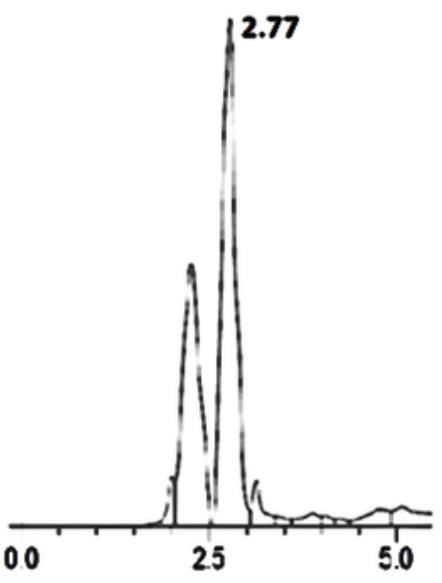

(b)

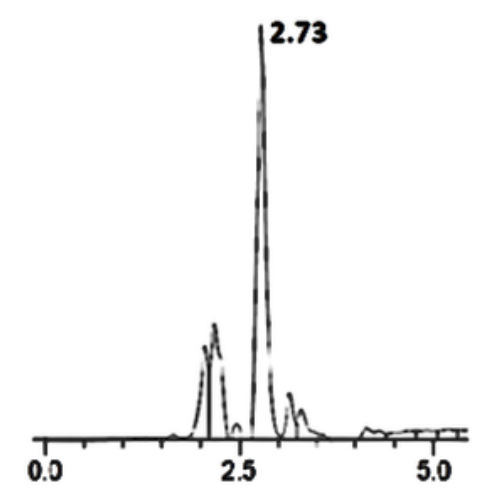

(c)

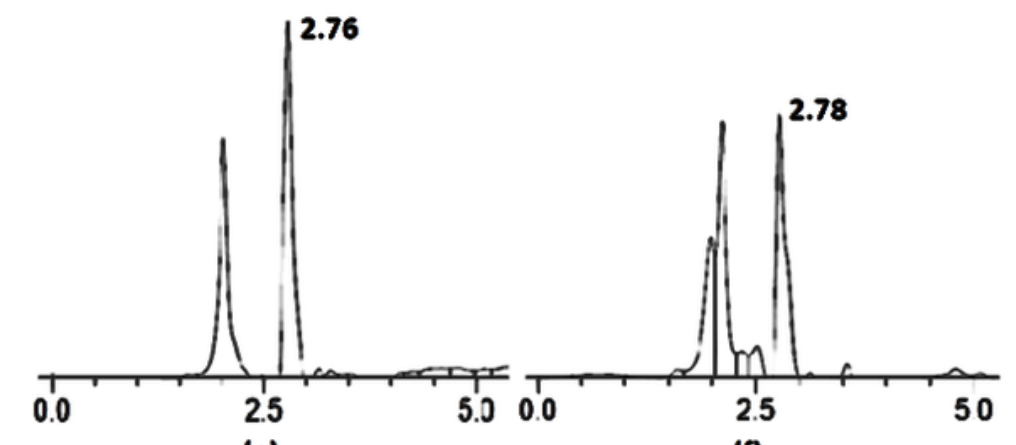

(e)

(f)

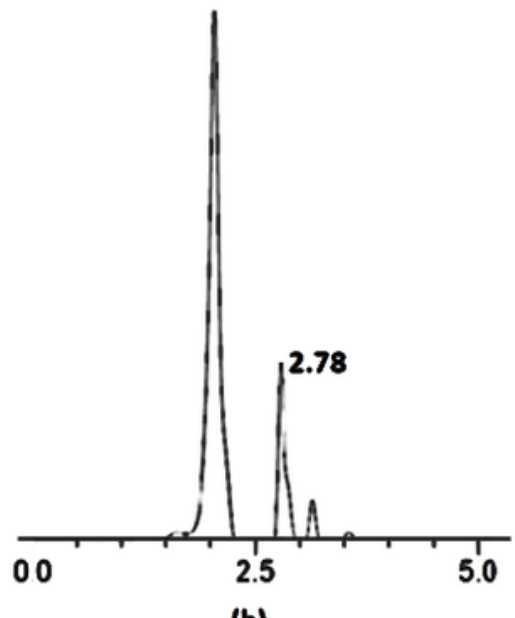

(h)

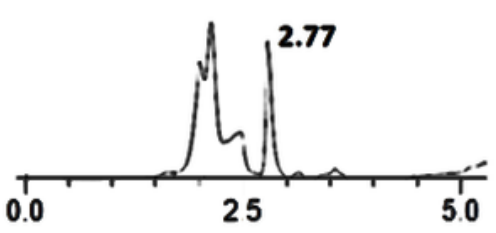

(I)

(min)

Figure 5

Chromatograms representing the detection level of fludioxonil in rice samples collected from (a) Khanewal, (b) Gularchi, (c) Badin, (d) Multan, (e) Hyderabad, (f) Lahore, (g) Jahania, (h) Sarghoda, (i) Makhdumpur 
This is a list of supplementary files associated with this preprint. Click to download.

- GraphicalAbstract.jpg 